\title{
Three new species of Lachemilla (Rosaceae) from South America
}

\author{
Diego F. Morales-Briones ${ }^{1,2, *}$, Katya Romoleroux ${ }^{3, *}$, David C. Tank ${ }^{2}$ \\ I Department of Plant and Microbial Biology, University of Minnesota, 140 Gortner Laboratory, 1479 Gort- \\ ner Avenue, Saint Paul, Minnesota, 55108, USA 2 Department of Biological Sciences and Stillinger Herba- \\ rium, University of Idaho, 875 Perimeter Drive MS 3051, Moscow, Idaho 83844-3051, USA 3 Herbario \\ QCA, Escuela de Ciencias Biológicas, Pontificia Universidad Católica del Ecuador, Av. 12 de Octubre 1076 y \\ Roca, Apartado 17-01-2184, Quito, Ecuador
}

Corresponding author: Diego F. Morales-Briones (dfmoralesb@gmail.com)

Academic editor: Alexander Sennikov | Received 20 May 2019 | Accepted 22 June 2019 | Published 19 July 2019

Citation: Morales-Briones DF, Romoleroux K, Tank DC (2019) Three new species of Lachemilla (Rosaceae) from South America. PhytoKeys 127: 93-119. https://doi.org/10.3897/phytokeys.127.36324

\begin{abstract}
Three new species of Lachemilla (Rosaceae), two from Colombia and one from Peru, are described and illustrated. Lachemilla rothmaleriana is characterized by its stout stems, sericeous-villous indumentum, and wide ascending sheaths with trilobate lateral lobes. Lachemilla argentea presents a unique combination of tripartite basal leaves with an adaxial silvery villous indumentum, and decumbent branches with verticillate lobed sheaths. Finally, Lachemilla cyanea has distinctly basal reniform leaves with a blue-green color and hirsute pubescence. Phylogenetic analyses of the nuclear ribosomal cistron and multiple regions of the plastid genome revealed the allopolyploid origin of the three new taxa.
\end{abstract}

\section{Resumen}

Tres nuevas especies de Lachemilla (Rosaceae), dos de Colombia y una de Perú, se describen e ilustran. Lachemilla rothmaleriana se caracteriza por tener tallos robustos, indumento sericeo-villoso, y verticilos anchos ascendentes con lóbulos laterales trilobados. Lachemilla argentea presenta una combinación única de hojas basales tripartitas con indumento villoso plateado en el haz y ramas decumbentes con verticilos lobulados. Finalmente, Lachemilla cyanea presenta hojas basales distintivas de forma reniforme, color azul-verdoso y pubescencia hirsuta. Análisis filogenéticos del cistrón ribosomal nuclear y múltiples regiones del genoma cloroplástico revelaron el origen alopoliploide de los tres nuevos taxones.

\section{Keywords}

Allopolyploidy, Colombia, Lachemilla, new species, páramo, Peru, Rosaceae

* These authors contributed equally to this work

Copyright Diego F. Morales-Briones et al. This is an open access article distributed under the terms of the Creative Commons Attribution License (CC BY 4.0), which permits unrestricted use, distribution, and reproduction in any medium, provided the original author and source are credited. 


\section{Introduction}

The genus Lachemilla (Focke) Rydb. is a morphologically diverse group that includes perennial herbs, subshrubs, and dwarf shrubs (Romoleroux 1996, 2004; Gaviria 1997). Lachemilla is distributed in the neotropical mountains from Mexico to Argentina and Chile, between 2,200 m and 5,000 $\mathrm{m}$ (Romoleroux 1996, 2004; Gaviria 1997), and it is especially common and diverse in the high elevation ecosystems of the Northern Andes where this group has undergone a rapid ecological radiation associated with the most recent Andean orogeny (Romoleroux 2004; Morales-Briones et al. 2018a).

The taxonomy of Lachemilla has proven challenging (e.g., Perry 1929; Rothmaler 1935a, 1935b, 1937), and although more recent regional treatments have reviewed this group (Gaviria 1997; Romoleroux 2004; Barrie 2015), the complex morphology of Lachemilla has obscured species boundaries and morphological subdivisions. Additionally, recent attention to the systematics of Lachemilla has resulted in the description of several new species (Romoleroux 2009; Romoleroux and Morales-Briones 2012; Morales-Briones 2016), but a comprehensive monographic revision of the genus is still needed (Romoleroux and Morales-Briones in prep.).

Based on molecular phylogenetic evidence, Morales-Briones et al. (2018a) proposed the recognition of 61 species of Lachemilla separated into four well-supported lineages that are somewhat congruent with previously morphology-based classification systems (Perry 1929; Rothmaler 1937). The Tripartite clade includes herbs with ascending and procumbent stems and tripartite leaves. The Verticillate clade includes subshrubs with erect or decumbent stems and reduced leaves that fuse with the stipules to form verticillate sheaths. The Pinnate clade comprises species with repent or decumbent stems and pinnate or bipinnatifid basal leaves. Finally, the Orbiculate clade encompasses species with a stoloniferous habit and palmately lobed leaves, and, it has been established that the Orbiculate clade is of ancient hybrid origin (Morales-Briones et al. 2018b). Moreover, Morales-Briones and Tank (2019a), using copies (or ribotypes) of the nuclear ribosomal (nrDNA) cistron and multiple regions of the plastid genome (cpDNA), showed that at least 30 species of Lachemilla are allopolyploids, and that this condition is widespread among the four main clades of this group.

Here, we describe and illustrate three new species of Lachemilla, two from Colombia and one from Peru, and using a phylogenetic approach, we show evidence that these new species are of allopolyploid origin.

\section{Materials and methods}

\section{Phylogenetic analyses}

We used previously published datasets from Morales-Briones and Tank (2019b) from the nrDNA cistron and 45 regions of cpDNA for Lachemilla, and included 68 samples representing 48 species of Lachemilla, seven samples of the three new taxa, and four outgroups (Appendix 1). DNA extraction, amplification and sequencing were 
carried out as described in Morales-Briones and Tank (2019a). Molecular datasets from Morales-Briones and Tank (2019a) and data for the new taxa presented here were generated simultaneously. Data processing and ribotype selection was performed as described in Morales-Briones and Tank (2019a). The three regions of the nrDNA (ETS, ITS1, and ITS2) were concatenated, and the 45 regions of the cpDNA were concatenated as well. Phylogenetic analyses of the nrDNA and cpDNA matrices were carried out independently to avoid conflicting phylogenetic signal due to widespread cytonuclear discordance in Lachemilla produced by polyploidy and ancient hybridization (Morales-Briones et al. 2018a, 2018b). Maximum likelihood (ML) analyses were conducted with RAxML v8.2.10 (Stamatakis 2014) using a GTRGAMMA model, 100 searches for the best tree, and clade support was assessed with 1,000 bootstrap replicates summarized using transfer bootstrap expectation (TBE; Lemoine et al. 2018). Bayesian inferences (BI) were performed with MrBayes v3.2.6 (Ronquist et al. 2012) on the CIPRES portal (Miller et al. 2010). Analyses consisted of two independent runs with four Markov Chain Monte Carlo (MCMC) chains for 20 million generations with trees sampled every $20,000^{\text {th }}$ generation and allowing sampling across the entire substitution rate model space using reversible-jump Markov Chain Monte Carlo $($ rjMCMC) $(n s t=$ mixed $)$ and rate variation set to GAMMA. Parameter estimate convergence of the independent MCMC runs was assessed by analyzing plots of all parameters and the $-\operatorname{lnL}$ after reaching an ESS (effective-sample size) $\geq 200$ using Tracer v1.6 (Rambaut et al. 2014). A 50\% majority rule consensus tree was generated and posterior probabilities (PP) were calculated after removing the first $25 \%$ of sampled trees. Alignments and phylogenetic trees are available at TreeBASE (http://purl.org/ phylo/treebase/phylows/study/TB2:S24437).

\section{Taxonomic analyses}

Morphological characters were studied using dried herbarium specimens of Lachemilla deposited in ANDES, CAS, COL, F, HUT, HAO, ID, JE, MEXU, MO, NY, QCA, TEX, and USM. Additionally, we reviewed species descriptions and types to determine the existence of the new taxa. The conservation status of the new species was evaluated using the guidelines of the International Union for Conservation of Nature (IUCN 2017).

\section{Results and discussion}

\section{Phylogenetic analyses}

The final cpDNA concatenated matrix included 65 sequences representing 47 species of Lachemilla and four outgroup species, and had an aligned length of 22,000 bp. The ML and BI analyses recovered the same overall topology (Fig. 1). The four major clades within Lachemilla are the same as in previous phylogenetic analyses of the genus (Morales-Briones et al. 2018a; Morales-Briones and Tank 2019a). The samples of 


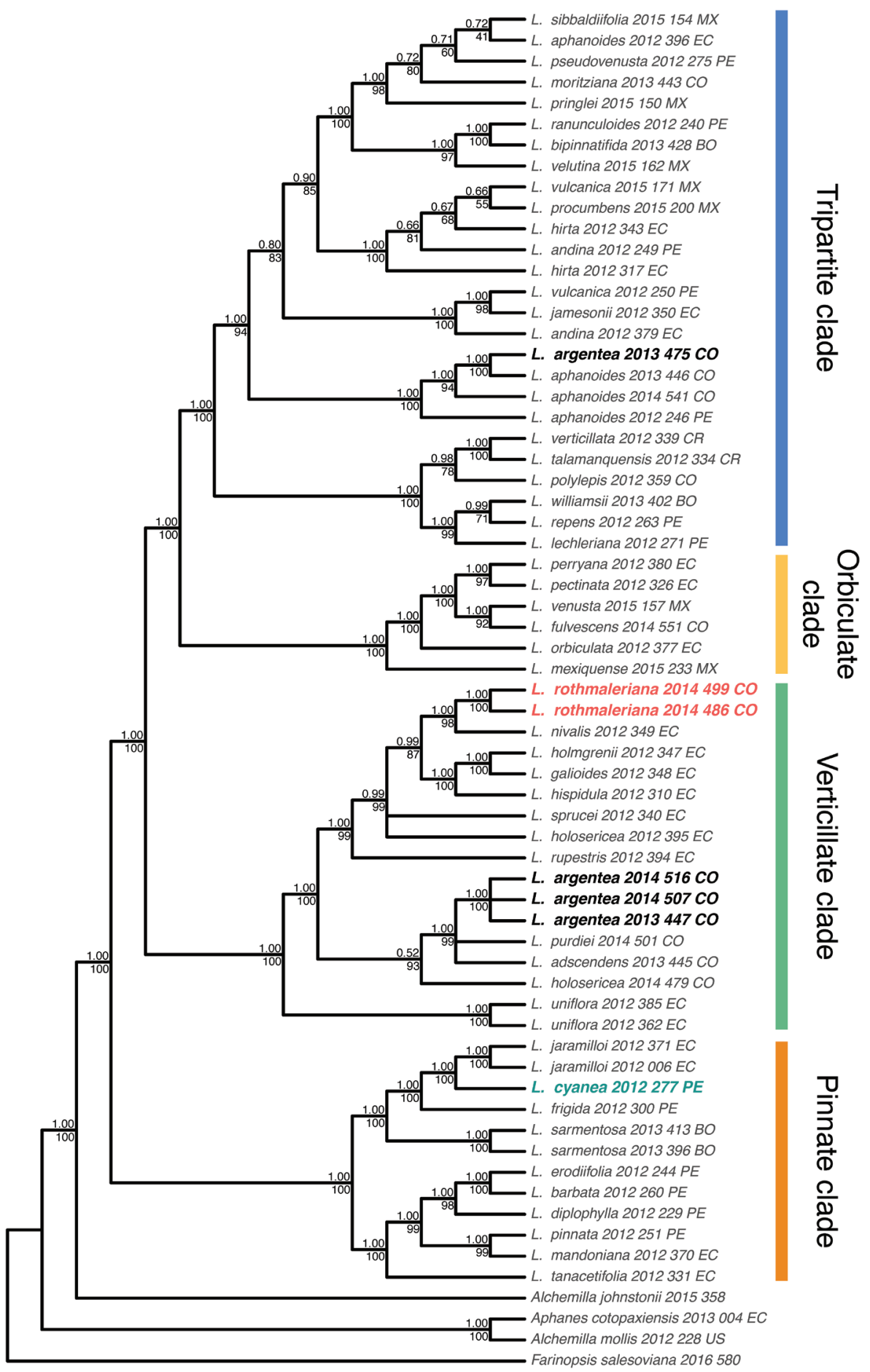

Figure I. Bayesian 50\% majority rule consensus tree of the cpDNA dataset. Posterior probabilities and transfer bootstrap expectation support values are shown above and below the branches, respectively. 


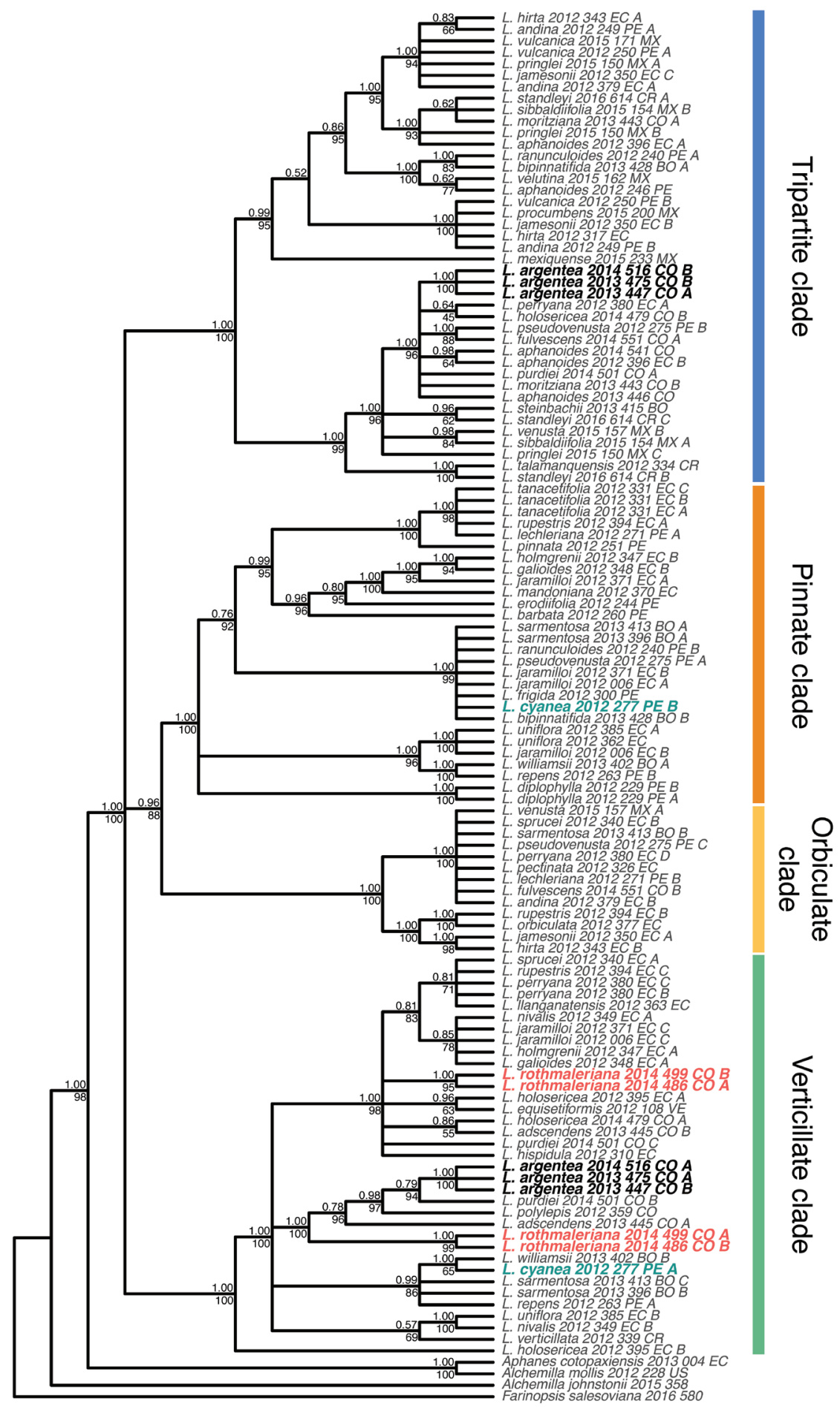

Figure 2. Bayesian 50\% majority rule consensus tree of the nrDNA dataset. Posterior probabilities and transfer bootstrap expectation support values are shown above and below the branches, respectively. 
L. rothmaleriana form a clade $(\mathrm{TBE}=100, \mathrm{PP}=1.0)$ and are placed as sister to $L$. nivalis (Kunth) Rothm. in the Verticillate clade. Lachemilla cyanea is placed in the clade (TBE $=100, \mathrm{PP}=1.0$ ) composed of $L$. frigida (Wedd.) Rothm. and L. jaramilloi Romol. \& D.F. Morales-B. (a known allopolyploid species) within the Pinnate clade. Lachemilla argentea is placed in two major clades. Three samples form a clade $(\mathrm{TBE}=100, \mathrm{PP}=$ 1.0) that is placed along other allopolyploid species (L. purdiei (L.M. Perry) Rothm., $L$. adscendens (Rothm.) Rothm. and L. holosericea (L.M. Perry) Rothm.) within the Verticillate clade. The remaining sample (2013_475_CO) is placed within a clade composed of only samples of $L$. aphanoides (Mutis ex L. f.) Rothm. within the Tripartite clade.

The final nrDNA concatenated alignment included 121 sequences representing 51 species of Lachemilla and four outgroup species, and had aligned length of $1038 \mathrm{bp}$. The ML and BI analyses also recovered the same overall topology (Fig. 2). As in the cpDNA analyses, the four major clades within Lachemilla are the same as in previous studies (Morales-Briones et al. 2018a; Morales-Briones and Tank 2019a). Lachemilla rothmaleriana showed the presence of two ribotypes within the Verticillate clade. One of the ribotypes is placed as sister $(\mathrm{TBE}=100, \mathrm{PP}=1.00)$ to a clade composed of L. adscendens, L. polylepis (Wedd.) Rothm., L. purdiei, and L. argentea. The second copy is placed within a clade $(\mathrm{TBE}=98, \mathrm{PP}=0.91)$ that includes several species with verticillate sheaths along the entire stem, like L. hispidula (L.M. Perry) Rothm., $L$. equisetiformis (Trevir.) Rothm., and $L$. nivalis, and several allopolyploid species (e.g. $L$. adscendens, L. holosericea, L. sprucei (L.M. Perry) Rothm.), but the resolution within this clade is rather uncertain. Lachemilla cyanea also presents two ribotype copies. One copy, as in the cpDNA tree, is placed in the clade $(\mathrm{TBE}=100, \mathrm{PP}=0.99)$ composed of L. frigida and its allopolyploid species (e.g. L. jaramilloi, L. sarmentosa (L.M. Perry) Rothm.) within the Pinnate clade. The other ribotype is placed within a clade (TBE $=86, \mathrm{PP}=0.99)$ composed only of allopolyploid species (L. williamsii (L.M. Perry) Rothm., L. repens (C. Presl) Rothm., and L. sarmentosa) within the Verticillate clade. All samples of $L$. argentea also have two ribotypes. The first is placed in the Tripartite clade along several allopolyploid species that involve $L$. aphanoides as one parental species (e.g. L. pseudovenusta, L. fulvescens (L.M. Perry) Rothm., L. purdiei, L. perryana (Rothm.) Rothm.). The second copy is placed as sister $(\mathrm{TBE}=84, \mathrm{PP}=0.79)$ to the allopolyploid species $L$. purdiei in the Verticillate clade.

Previous phylogenetic analysis of Lachemilla have shown that allopolyploidy is common in this group with at least 30 species confirmed to be of allopolyploid origin (Morales-Briones and Tank 2019a). Here we show that the three new taxa of Lachemilla described here are also allopolyploids. Lachemilla rothmaleriana appears to be an allopolyploid of two different species within the Verticillate clade. Based on the cpDNA tree we can determine that $L$. nivalis might be the maternal lineage, while the paternal lineage seems to be the same as in the allopolyploids $L$. adscendens, $L$. purdiei and $L$. argentea, all from Colombia. From the nrDNA tree we can see that the paternal species is either extinct or unsampled. Morphologically, L. rothmaleriana presents the main characteristic of the Verticillate clade, which is the presence of reduced leaves that fuse with the stipules to form verticillate sheaths, but this new taxon is distinguished mainly by 
the presence of wide ascending sheaths with trilobate lateral lobes and a dense sericeousvillous indumentum (see Taxonomic treatment for details). The presence of divided lobes is a characteristic of other species of the Verticillate clade that are now known to be of hybrid origin, like L. adscendens and L. sprucei (Morales-Briones and Tank 2019a).

Lachemilla argentea is also an allopolyploid species of two major clades. The cpDNA tree shows that three of the four samples have the maternal lineage from the Verticillate clade, while for one sample (2013_475_CO) the maternal lineage is L. aphanoides in the Tripartite clade. The nrDNA data shows that the paternal lineage of $L$. argentea is in the Tripartite clade, except for 2013_475_CO which has an extinct or unsampled parental lineage in the Verticillate clade. Although the sample 2013_475_CO is monophyletic with the other samples of this species for both ribotypes in the nrDNA, the different position in the cpDNA tree is clear evidence that the parental contribution in the formation of allopolyploid species in Lachemilla can work in both directions, as well as the recurrent origin of allopolyploids, which has also been previously shown for this group (Morales-Briones and Tank 2019a), and is known for other related groups in Rosaceae, like Fragaria (Dillenberger et al. 2018). The basal tripartite leaves of Lachemilla argentea are characteristic of the Tripartite clade, but its decumbent branches with verticillate lobed sheaths resemble the Verticillate clade (see Taxonomic treatment for details).

Finally, L. cyanea also shows evidence of an allopolyploid origin between two major clades. The maternal species appears to be $L$. frigida in the Pinnate clade, which is also the maternal lineage of L. jaramilloi (Morales-Briones and Tank 2019a), with which L. cyanea also shares a rosette habit (see Taxonomic treatment for details). The paternal lineage appears to be the same as in the allopolyploid and morphologically similar species $L$. williamsii, L. repens, and $L$. sarmentosa in the Verticillate clade, where the parental lineage of these species has been shown likely to be extinct (Morales-Briones and Tank 2019a). Interestingly, these three similar species are hybrids of three different major clades (Pinnate, Verticillate, and Tripartite; Morales-Briones et al. 2018a). Given its tripartite leaf and glomerulate inflorescence (see Taxonomic treatment for details), L. cyanea also shares characteristics with the Tripartite clade, but we were not able to obtain evidence of this from the nrDNA tree, which can be explained by omission nrDNA copies during bioinformatic processing of the PCR amplicon pools as seen in other species of Lachemilla (Morales-Briones and Tank 2019a).

\section{Taxonomic treatment}

Lachemilla rothmaleriana D.F.Morales-B. \& Romol., sp. nov. urn:lsid:ipni.org:names:77199640-1

Figs 3-5

Diagnosis. Lachemilla rothmaleriana differs from L. hispidula (L.M. Perry) Rothm. and L. nivalis (Kunth) Rothm. by its stout stems, sericeous-villous indumentum, wide ascending sheaths with trilobate lateral lobes, and a turbinate-campanulate hypanthium. 


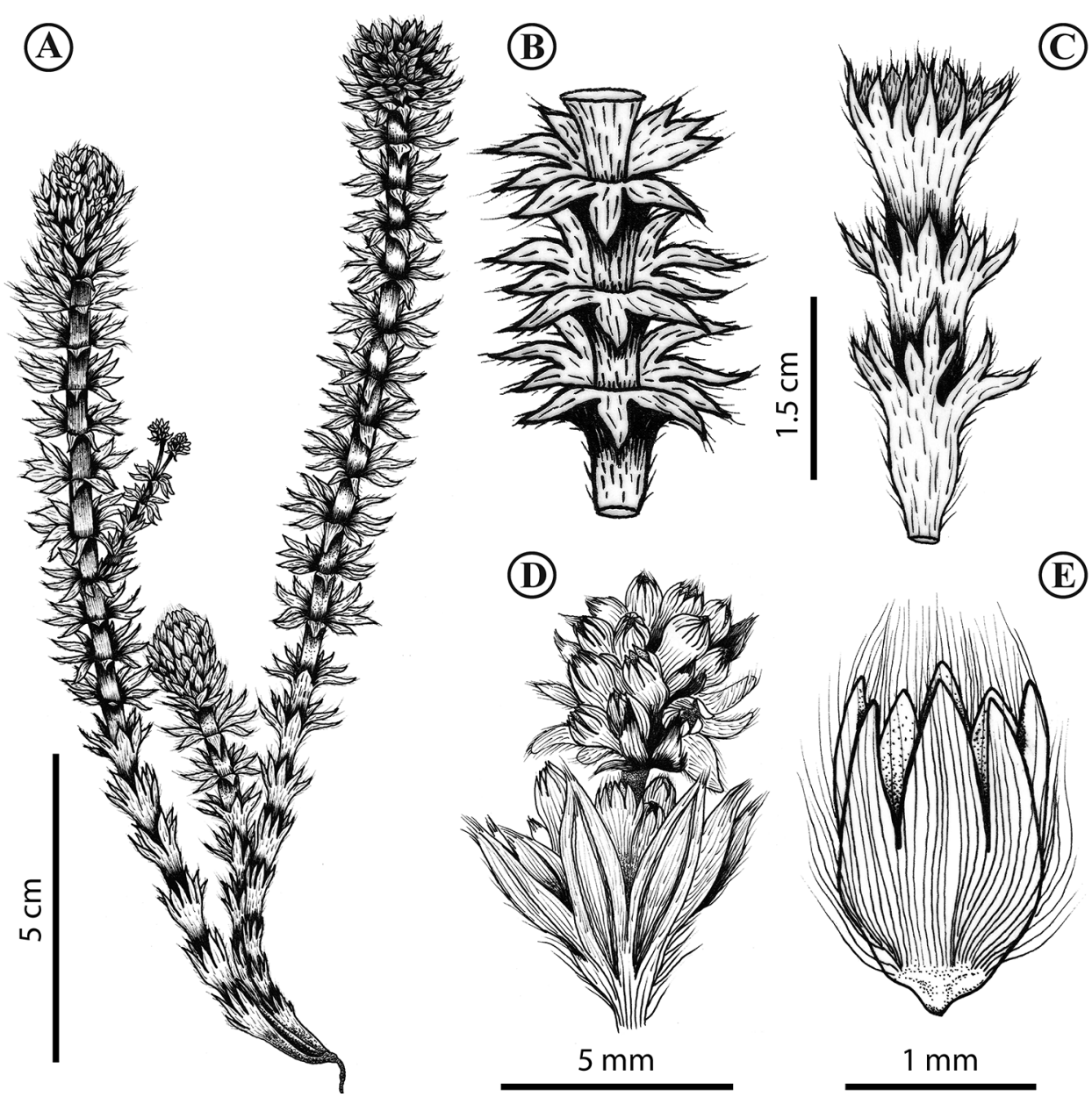

Figure 3. Lachemilla rothmaleriana. A Habit $\mathbf{B}$ stem, apical leaves $\mathbf{C}$ stem, basal leaves $\mathbf{D}$ flowering branch $\mathbf{E}$ flower. Illustration by S. Cordero.

Type. COLOMBIA. Boyacá: Duitama. Road to páramo de la Rusia, $22 \mathrm{~km}$ from Duitama, before 'fábrica de arepas Buenos Aires', 5.92656N, 73.08826W, alt. $3650 \mathrm{~m}$, 24 September 2013, Morales-Briones D.F. \& Uribe-Convers S. 506. (holotype: ID!, isotypes: ANDES!, QCA!).

Description. Ascendent subshrubs; stems erect to slightly decumbent, up to 22$27 \mathrm{~cm}$ long, robust, densely sericeous-villous, branched at apex. Basal stipules usually caducous, if present 5-6 mm long, adnate to the petiole at base, free at apex, entirely membranous, brown. Basal leaves usually caducous, if present 3-6-lobed, 4-6 $\times 3-6 \mathrm{~mm}$; basal petiole 3-4 mm long. Distal leaves reduced, adnate, and connate to the distal stipules forming verticillate, lobed sheaths; sheath lobes $7-8$, ascending to spreading at maturity, lanceolate, one lobe 3-5 lobate, lobes (4) 6-8 × 1-2 (4) mm, ( $2 / 3$ of the entire sheath length), chartaceous, margin revolute, lower surface appressed 


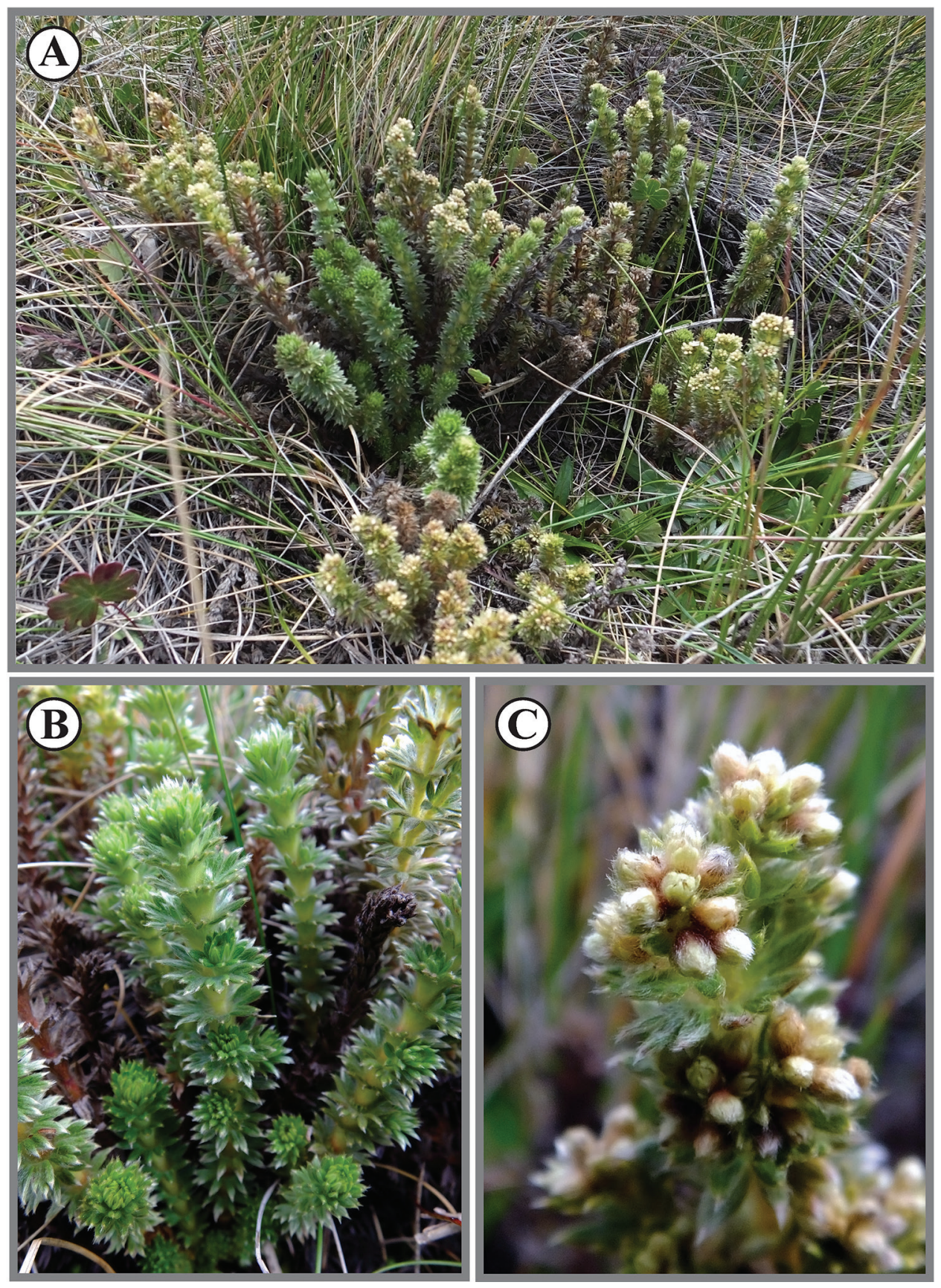

Figure 4. Lachemilla rothmaleriana. A Habit B stems C flowering branch.

sericeous-villous to villous, upper surface sericeous-villous to glabrescent. Inflorescences terminal or axilar \pm glomerulate cymes; floral bracts lobed, ascending; 8-10 flowers per inflorescence; pedicels $0.3-0.4 \mathrm{~mm}$ long, pilose. Flowers $1.5-2.5 \mathrm{~mm}$ long; hypan- 


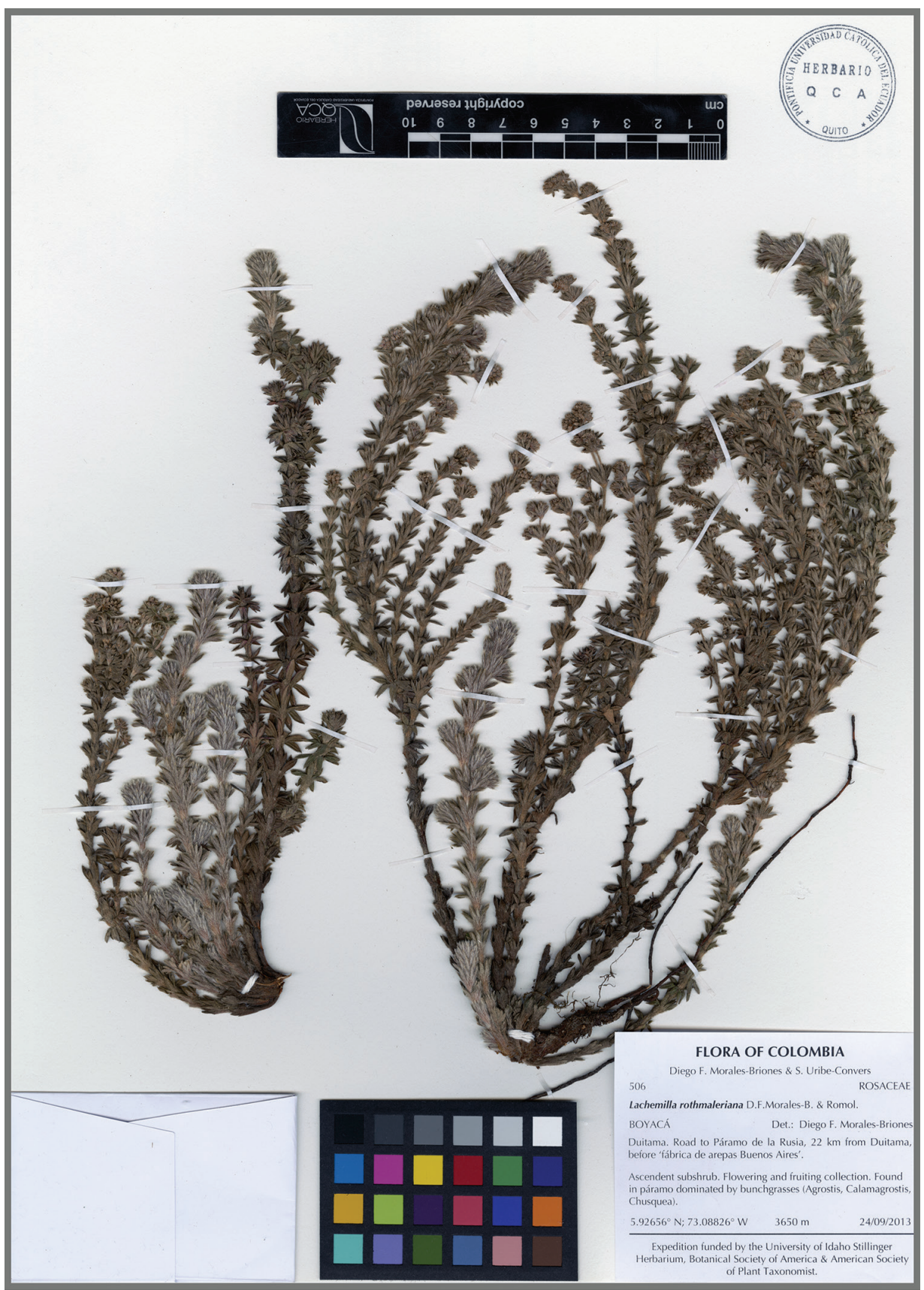

Figure 5. Lachemilla rothmaleriana. Isotype collection: Morales-Briones D.F. \& Uribe-Convers S. 506. (QCA).

thium turbinate-campanulate, brown-reddish at base, pilose-sericeous outside slightly glabrescent at base, glabrous within; 4 episepals and 4 sepals connivent to \pm straight, abaxially sericeous, adaxially glabrous; episepals narrowly ovate, $0.8-1 \times 0.2-0.3 \mathrm{~mm}$, 


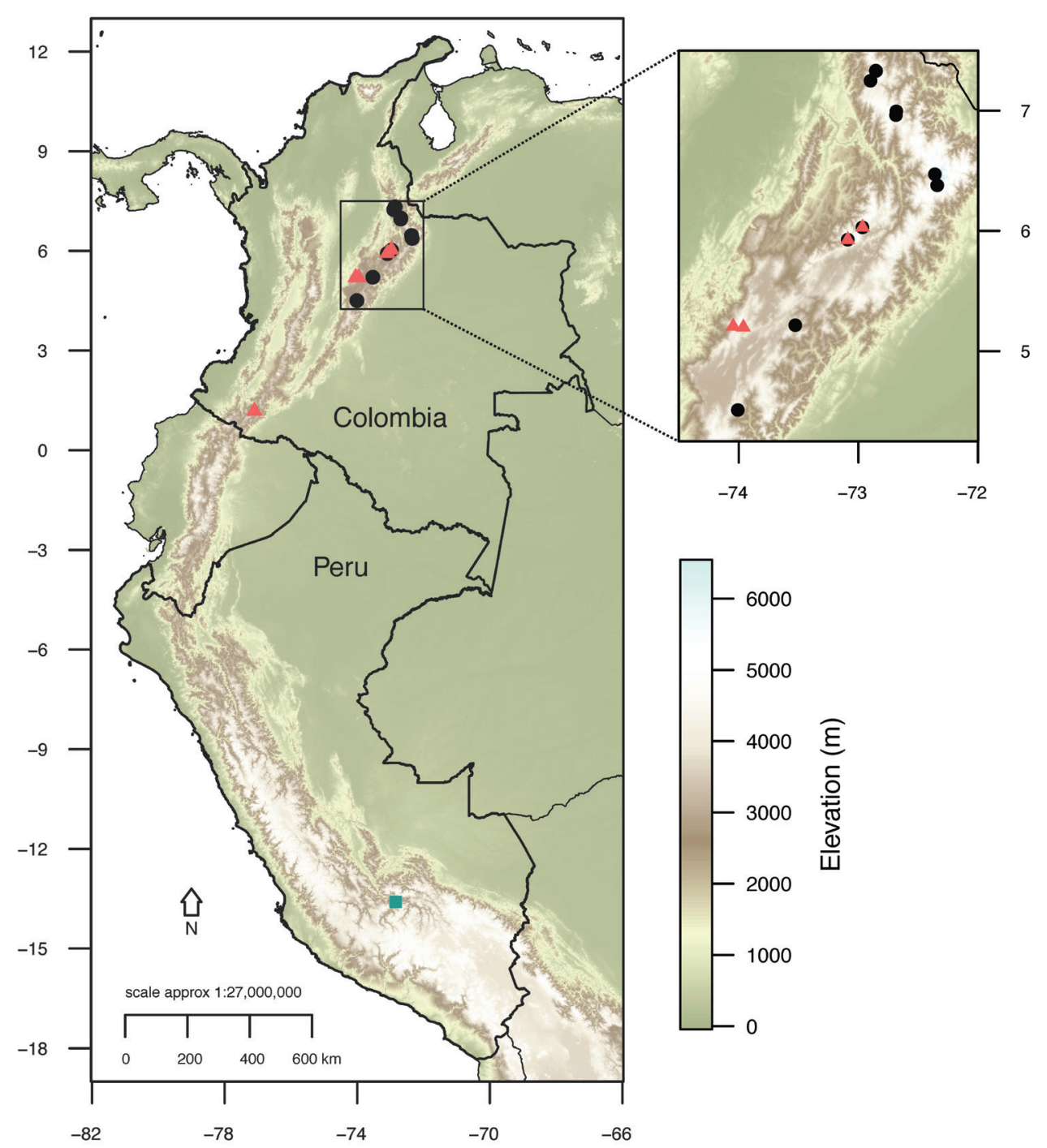

Figure 6. Geographic distribution of Lachemilla rothmaleriana (read triangles), L. argentea (black circles), and L. cyanea (cyan rectangle).

apex acute; sepals ovate, $0.5-1 \times 0.4-0.5 \mathrm{~mm}$, apex \pm acute; stamens 2 adnate to the floral disc; carpels 2 (3), stigma clavate. Two achenes $0.8-0.9 \times$ ca. $0.5 \mathrm{~mm}$, subovoid.

Distribution and ecology. Lachemilla rothmaleriana has a scattered distribution in the northcentral region of the Cordillera Oriental and in the southern part of the Cordillera Central of the Colombian Andes, between 3250 and $3768 \mathrm{~m}$ (Fig. 6). This species is mainly found in páramos dominated by bunchgrasses (Agrostis, Calamagrostis, Chusquea) and lives in sympatry with L. hipidula, L. nivalis, and L. purdiei. Flowering and fruiting collections dated from the months of January, May, September, and December. 
Etymology. The specific epithet honors Prof. Dr. Werner Rothmaler (1908-1962), a German botanist who studied Lachemilla in detail and described over 20 species of this genus.

Conservation status. Lachemilla rothmaleriana is known only from the three localities that are zones impacted by human activities, including conversion to agriculture. Following the IUCN (2017) guidelines, based on the reduced geographic distribution and altered land use at the type locality, this species should be categorized as vulnerable (VU).

Additional specimens examined. COLOMBIA. Putumayo: Comisaria del Putumayo, Alta cuenca del río Putumayo, filo de Cordillera entre El Encano y Sibundoy, páramo de San Antonio del Bordoncillo, 1.18333N, 77.1000W, alt. 3250 m, 4 January 1941, Cuatrecasas J. 11761 (COL, F, JE frag.). Santander: Páramo del Consuelo, Belén, Vereda de San José, $18 \mathrm{~km}$ from Belén on road to Encino, 6.02920N, 72.96523W, alt. 3768 m, 23 September, 2013, Morales-Briones D.F. \& Uribe-Convers S. 492 (ANDES, ID, QCA).

Notes. Lachemilla rothmaleriana resembles $L$. hispidula and $L$. nivalis by its habit and erect stems with reduced leaves that fuse with the stipules to form verticillate sheaths, but differs by having trilobate lateral lobes. Additionally, L. hispidula has an overall hispid pubescence, while $L$. rothmaleriana has a characteristic sericeous-villous indumentum. Moreover, $L$. rothmaleriana has a turbinate-campanulate hypanthium with pilose-sericeous pubescence, while $L$. hispidula has a globose-campanulate hypanthium with pilose-hirsute pubescence. Lachemilla nivalis has a hypanthium with similar indumentum but its shape is only slightly campanulate. In the shape of sheath lobes, L. rothmaleriana somewhat resembles L. galioides (Benth.) Rothm., but the latter has slender stems, broader sheath lobes, and villous-hispid indumentum.

\section{Lachemilla argentea D.F.Morales-B. \& Romol., sp. nov.} urn:Isid:ipni.org:names:77199641-1

Figs 7-9

Diagnosis. Lachemilla argentea differs from $L$. holmgrenii Rothm. and L. adscendens (Rothm.) Rothm. by its herbacecous habit with decumbent branches, conspicuous basal reniform tripartite leaves with an adaxial silvery villous pubescence, and a turbinate to urceolate hypanthium with pilose-sericeous pubescence.

Type. COLOMBIA. Bogotá, Distrito Capital: Páramo de Cruz Verde. Path to Laguna El Verjón, 4.56102N, 74.02172W, alt. 3495 m, 26 September 2013, MoralesBriones D.F. \& Uribe-Convers S. 523 (holotype: ID!, isotypes: ANDES!, QCA!).

Description. Decumbent herbs; branches decumbent up to $12 \mathrm{~cm}$ long, sericeousvillous. Basal stipules $5-10 \mathrm{~mm}$ long, adnate to the petiole, sparsely villous, membranous, brown at base, free at apex. Basal leaves tri-parted, blade reniform in outline, 6-7 (-10) x 7.5-10 (-1.3) mm, 3 lobes, chartaceous, slightly plicate, lobes unequally obovate-rhomboid, margin dentate-incised, teeth 3-6 on each of the lobes, lower sur- 


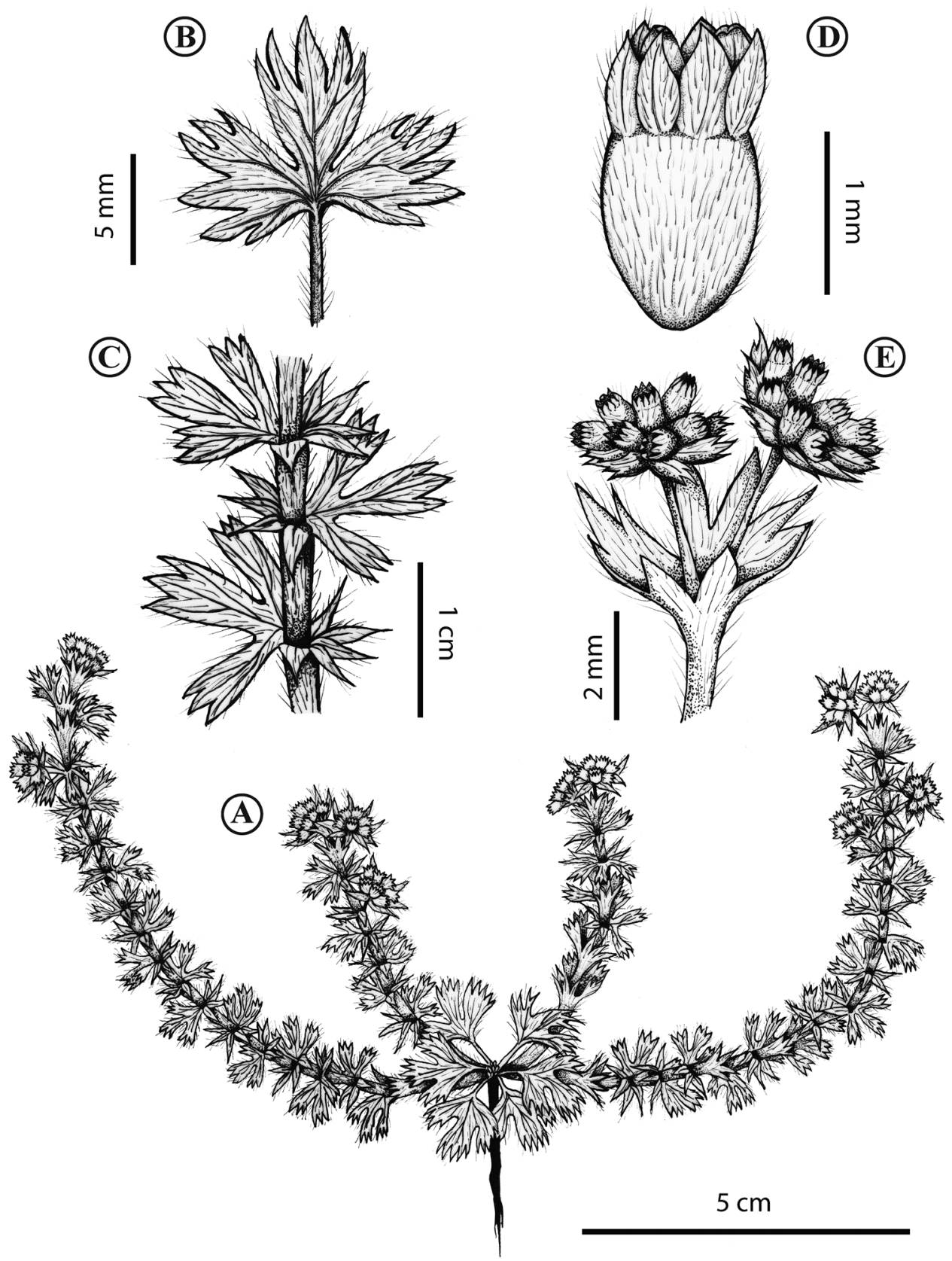

Figure 7. Lachemilla argentea. A Habit B basal leaf $\mathbf{C}$ stem, apical leaves $\mathbf{D}$ flower $\mathbf{E}$ flowering branch. Illustration by C. Rodríguez.

face sparsely sericeous-villous, upper surface villous; basal petiole 5-12 mm long. Distal stipules and distal leaves reduced adnate and connate, forming verticillate lobed sheaths; sheath lobes 6-10 ascending or slightly spreading; lobes 4-7 $\times 1.5-3 \mathrm{~mm}$, 
lanceolate, entire or trilobed, decreasing in size. Inflorescences axilar or terminal glomerulate cymes, flowers aggregate at the distal part. Floral bracts $2-4 \mathrm{~mm}$ long, free, incised, and ascending; 3-7 flowers per inflorescence; pedicels $0.5-1 \mathrm{~mm}$ long, slightly pilose. Flowers $2-2.5 \mathrm{~mm}$ long; hypanthium turbinate to urceolate, green or reddish, pilose-sericeous outside, glabrous within; 4 episepals and 4 sepals green or slightly reddish, straight, abaxially pilose-sericeous, adaxially glabrous; episepals triangular, 0.7$0.8 \times 0.4-0.5 \mathrm{~mm}$, apex acute; sepals triangular-ovate, $0.75-0.85 \times 0.5-0.6 \mathrm{~mm}$, apex acute; stamens 2 adnate to the floral disc; carpels 2-3, stigma clavate. Two achenes, ca. $1-1.5 \times 0.6-0.8 \mathrm{~mm}$, globose-ovoid.

Additional specimens examined. COLOMBIA. Bogotá, Distrito Capital: Páramo de Cruz Verde, Bogotá-Choachí road, km 11.2, alt. 3257 m, 1 May 1972, Cleef A. $3330 A$ (COL). Bogotá, Distrito Capital: Páramo de Cruz Verde, path to Laguna El Verjón, 4.56102N, 74.02172W, alt. 3495 m, 26 September 2013, Morales-Briones D.F. \& Uribe-Convers S. 522 (ANDES, ID, QCA). Boyacá: Güicán, Sierra Nevada del Cocuy, road to the small house, in 'Lagunilla' area, towards to Púlpito del Diablo, 6.37906N, 72.33995W, alt. 3950 m, 18 September 2013, Morales-Briones D.F. et al. 476 (ANDES, ID, QCA). Boyacá: Duitama, road to Páramo de la Rusia, $22 \mathrm{~km}$ from Duitama, before 'fábrica de arepas Buenos Aires', 5.92656N, 73.08826W, alt. 3650 m, 24 September 2013, Morales-Briones D.F. \& Uribe-Convers S. 507 (ANDES, ID, QCA). Boyacá: Belén, Vereda de San José, Páramo del Consuelo, $18 \mathrm{~km}$ from Belén, on the way to Encino, 6.02920N, 72.96523W, alt. 3768 m, 23 September 2013, Morales-Briones D.F. \& UribeConvers S. 499 (ANDES, ID, QCA). Boyacá: Páramo de Pisba, Socha-La Punta road, $\mathrm{km} 72$, near to M.O.P campsite. El Cadillal, stony slope, alt. $3500 \mathrm{~m}, 8$ June 1972, Cleef A. 4235 (COL). Boyacá: Páramo NW of Belén, Vereda S. José de la Montaña, Alto de las Cruces and surroundings, alt. 3790 m, 24 February 1972, Cleef A. 1756 (COL). Boyacá: Páramo de Pisva, Socha-La Punta road, km 61, 5.6 km east of Los Pinos, Alto de Granados, alt. 3635 m, 12 June 1972, Cleef A. 445813 (COL). Boyacá: Páramo de Pisva, flank SW of Morros de S. Gabriel, 2 km SW of Laguna Batanera, alt. 3670 m, 18 June 1972, Cleef A. $4702 A$ (COL). Cundinamarca: Villa Pinzón, Páramo de Guachenque. Entrance to the Laguna del Valle and surroundings of Laguna del Mapa, 5.21641N, 73.52675W, alt. 3346 m, 25 September 2013, Morales-Briones D.F. \& Uribe-Convers S. 514 (ANDES, ID, QCA). Cundinamarca: Páramo de Palacio, $18 \mathrm{~km}$ from the road, alt. $3485 \mathrm{~m}, 16$ December 1971, Cleef A. 327 (COL). Santander: Vetas, road to the Laguna Pajaritos, at the entrance of private property, $7.33349 \mathrm{~N}, 72.85373 \mathrm{~W}$, alt. $3539 \mathrm{~m}$, 14 September 2013, Morales-Briones D.F. et al. 437 (ANDES, ID, QCA). Santander: Vetas, road to Laguna Pajaritos, 7.33086N, 72.85106W, alt. 3585 m, 14 September 2013 MoralesBriones et al. D.F. 440 (ANDES, ID, QCA). Santander: Páramo de Almorzadero, road Presidente-Cerrito, km 98, 6.99470N, 72.68187W, alt. 3567 m, 16 September 2013, Morales-Briones D.F. et al. 458 (ANDES, ID, QCA). Santander: Páramo de Almorzadero, road Presidente-Cerrito, km 98, 6.96333N, 72.68488W, alt. $3801 \mathrm{~m}, 16$ September 2013, Morales-Briones D.F. \& Uribe-Convers S. 459 (ANDES, ID, QCA).

Mixed specimens examined. the following specimens are collections with two different species under the same number, one (a) correspond to L. argentea. Boyacá: 

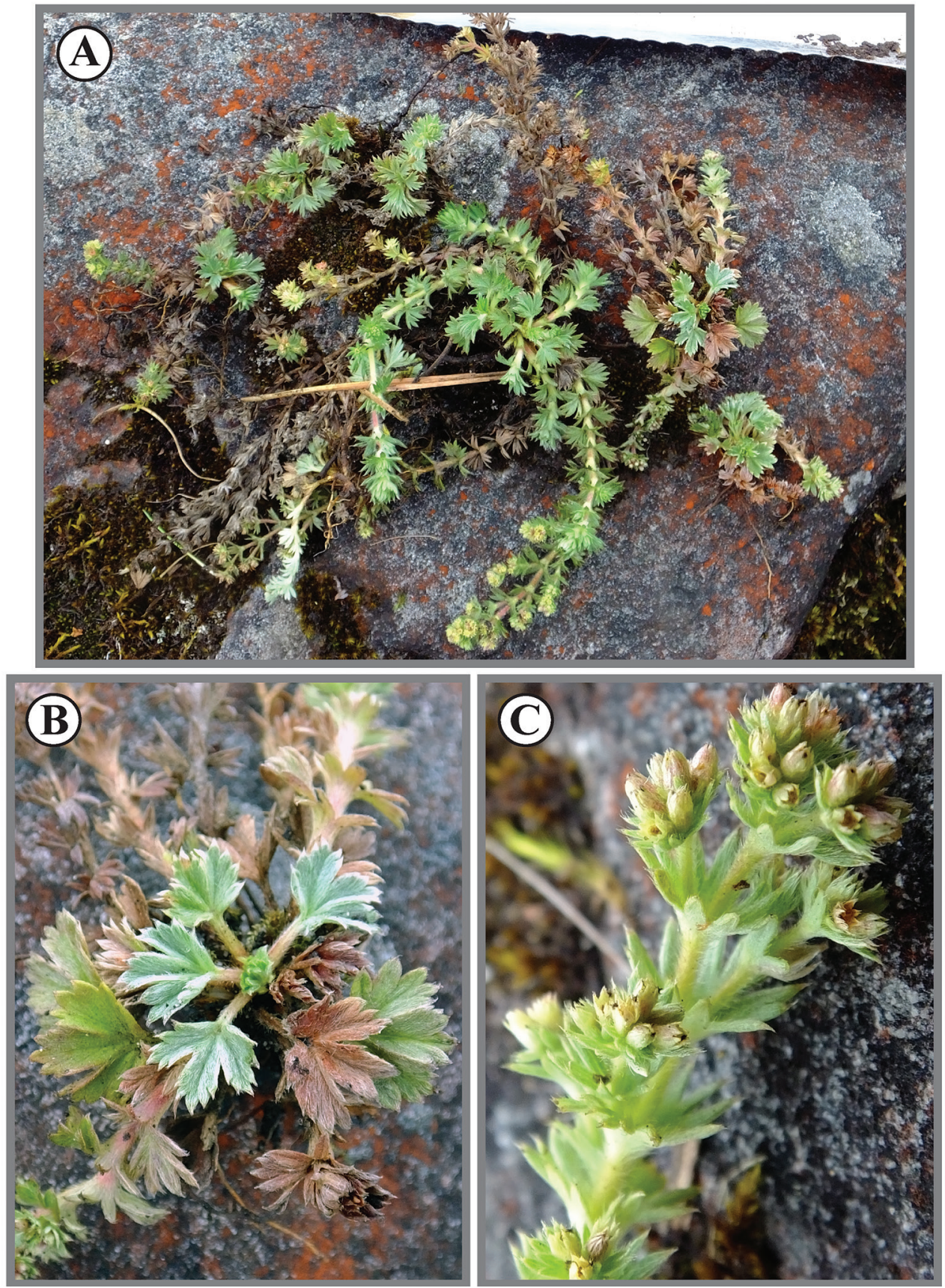

Figure 8. Lachemilla argentea. A Habit B basal leaves $\mathbf{C}$ flowering branch.

Páramo de Pisva, Alto de Granados, 5 km E of Los Pinos, alt. 3735m, 15 June 1972, Cleef A. 4593A (a) (COL). Boyacá: Güicán Sierra Nevada del Cocuy, after Cabañas Kanwara, 17.7 km from 'water plant', Lomas Las Pajas, 6.47093N, 72.35934W, 
alt. 4105 m, 17 September 2013, Morales-Briones D.F. \& Uribe-Convers S. 473 (a) (ANDES, ID, QCA). Santander: Páramo de Santurbán, Berlín, 7 km from Vetas, 7.24935N, 72.89784W, alt. 3567 m, 13 September 2013, Morales-Briones D.F. et al. 431 (a) (ANDES, ID, QCA).

Deviating specimens examined. The following specimens have similar habit, leaf shape, and pubescence to L. argentea, but they only differ in having glabrous flowers. These specimens may represent only a variety of $L$. argentea, but they are maintained here as uncertain taxa until more material is available or can be included in phylogenetic analyses. Boyacá: Páramo NW of Belén, Quebrada Minas. Hoya CLLA, Slopes N of Valle Lajas, alt. 3835m, 2 March 1973, Cleef A. 2119A (COL). Boyacá: Páramo de Pisva, Road Socha-La Punta, km 61.5, 6 km E from Los Pinos Alto de Granados, alt. 3630 m, 14 June 1972, Cleef A. 4545 (COL). Cundinamarca: Páramo de Palacio aprox. $1 \mathrm{~km}$ E from 'la mina de cal', alt. $3853 \mathrm{~m}, 19$ May 1972, Cleef A. 3853 A (COL). Quidio/Tolima: Paramillo of Quindio and Páramo de Tolima. $13 \mathrm{~km}$ from Valle de Cocora. 4.64433N, 75.43060W, alt. 3645 m, 4 October 2013, Morales-Briones D.F. et al. 543 (ANDES, ID, QCA). Santander: Vetas, road to Laguna Pajaritos, 7.33086N, 72.85106W, alt. 3585 m, 14 September 2013, Morales-Briones D.F. et al. 439 (ANDES, ID, QCA).

Distribution and ecology. Lachemilla argentea is distributed in the central northern (primarily) regions of the Cordillera Oriental between 3275 and 3735 m (Fig. 6). This species occurs in humid and very humid páramos dominated by grasses, shrubs, and dwarf shrubs. Lachemilla argentea can be found living in sympatry with multiple species of Lachemilla, including L. aphanoides, L. hispidula, L. nivalis, L. mandoniana (Wedd.) Rothm., L. purdiei, and L. vulcanica (Schltdl. \& Cham.) Rydb. Flowering and fruiting collections dated from the months of February, May, June, and September.

Etymology. The specific epithet refers to the silvery aspect of the basal leaves.

Conservation status. Lachemilla argentea is a common element throughout its distributional range, and occurs in several well-conserved areas. Following the IUCN (2017) guidelines, we consider this species is not at risk and should be categorized as least concern (LC). Nonetheless, the rapid deterioration and conversion to agriculture of proximate areas where $L$. argentea occurs may put this species at some threat in the near future.

Notes. Lachemilla argentea resembles $L$. holmgrenii and $L$. adscendens by having basal tripartite leaves and stem leaves fused to the stipules forming verticillate sheaths with one tripartite lobe that is larger than the remaining lobes, but differs in having an herbaceous habit with decumbent branches, while the other two species are subshrubs with suberect to ascending branches. Furthermore, L. argentea has conspicuous basal reniform tripartite leaves with an adaxial silvery villous pubescence, while $L$. holmgrenii and $L$. adscendens have smaller hirsute leaves. These species also vary in the number of sheath lobes; $L$. argentea has 6-10 ascending or slightly spreading lobes, while $L$. holmgrenii and $L$. adscendens have 5-7 loosely ascending to reflexed lobes, and eight erecto-patent lobes, respectively. By having conspicuous basal leaves, $L$. argentea also resembles $L$. sprucei, but the latter is a subshrub with suberect stems and coriaceous 5-parted basal leaves, in addition to distinct 3-parted distal leaves. 


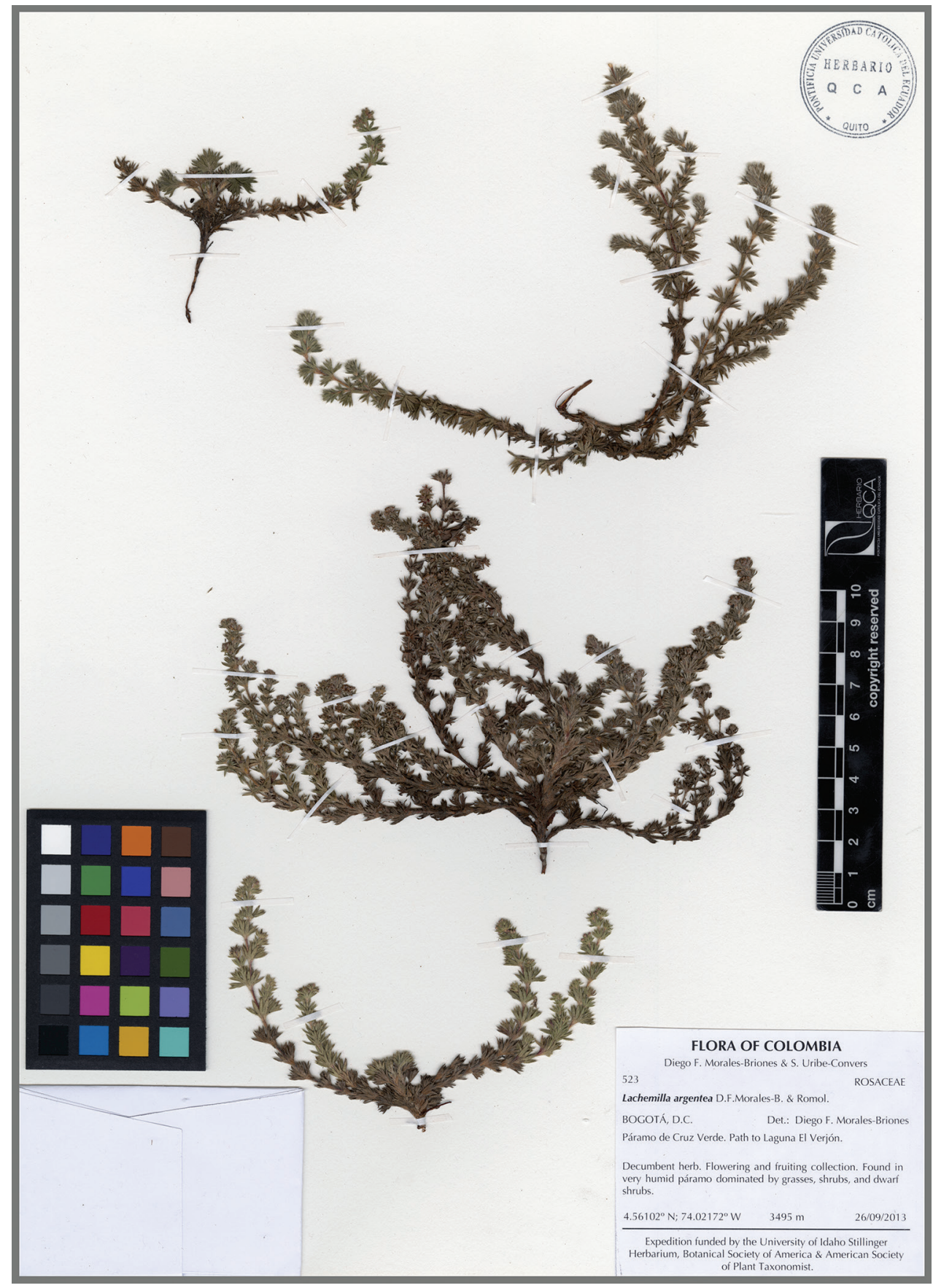

Figure 9. Lachemilla argentea. Isotype collection: Morales-Briones D.F. \& Uribe-Convers S. 523 (QCA). 
Key to Lachemilla rothmaleriana, L. argentea, and similar species of the Verticillate clade from Colombia

Notes. Includes species with stem leaves fused to the stipules forming verticillate sheaths (sect. Nivales and sect. Subnivales; sensu Rothmaler 1935a). Accepted taxa and synonymy follows Morales-Briones et al. (2018a). Adapted in part from Perry (1929) and Romoleroux (2004).

1 Subshrubs with erect or decumbent stems; basal leaves caducous or sessile when present; stem leaves reduced, with the adnate stipule forming verticillate sheaths along the entire stem ..........................................................................2 2

- Herbs with procumbent or decumbent stems, or subshrubs with suberect or \pm decumbent stems; basal leaves petiolate; lower stem leaves subequal to or often longer than the stipules, 3-parted or 3-lobed, uppermost stem leaves reduced, with the adnate stipule forming verticillate sheaths ...............................8

2 Outer surface of sheath lobes glabrous or puberulent; lobes $4-6$.................... 3

- $\quad$ Outer surface of sheath lobes conspicuously pubescent; lobes $4-15$...............4 4

3 Outer surface of sheath lobes glabrous and reticulate, margins strongly revolute .

L. equisetiformis

- Outer surface of sheath lobes hispidulous and not reticulate, margins revolute at apex L. ericoides

4 Plants pilose, villous or sericeous; sheath lobes laxly ascending to erect, basal leaves mainly caducous...................................................................5

- Plants hispid, hirsute or villous; sheath lobes widely spreading to abruptly reflexed; basal leaves usually present (except in L. verticillata)............................6

5 Stems sparsely villous, pilose to glabrescent, or sericeous; sheath lobes 10-15, linear to linear-lanceolate, all lobes entire ....................................... nivalis

- Stems densely sericeous-villous; sheath lobes 7-8, lanceolate, one lobe 3-5 lobate.

L. rothmaleriana

6 Sheath lobes 7-8 (10); stems villous; sepals and episepals divergent and equal in length; hypanthium villous

L. verticillata

- $\quad$ Sheath lobes 9-13; stems hispid or hirsute; sepals and episepals connivent, episepals usually a little shorter than the sepals

7 Plant copiously hirsute; sheath lobes reflexed; hypanthium glabrous ...L. galioides

- $\quad$ Plant sparsely hispid; sheath lobes spreading; hypanthium glabrous or pubescent L. hispidula

8 Caespitose herbs; stems procumbent or slightly decumbent, multiple branched and rooting

- Herbs or subshrubs; stems suberect or \pm decumbent, not branched and not rooting

9 Flowers ca. 2-2.5 mm long, hypanthium campanulate, appressed villous, carpels 5-10; stigma clavate.

- Flowers ca. $3.5 \mathrm{~mm}$ long, hypanthium globose-urceolate, sericeous-villous, carpels 5; stigma subclavate. 
10 Basal leaves 5-parted, coriaceous; flowers ca. 2.5-3.5 long; carpels 5-6...L. sprucei

- Basal leaves 3-parted, not coriaceous; flowers ca. 2-2.5 long; carpels 2-4 ........11

11 Herbs, sericeous-villous; stems decumbent; sheath lobes 6-10, ascending or slightly spreading ...................................................................... a argentea

- Subshrubs, villous or hirsute; stems suberect or ascending, sheath lobes 5-8,

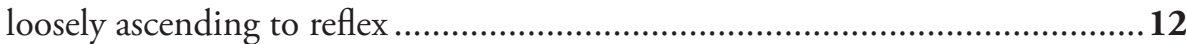

12 Stems suberect; sheath lobes 5-7; hypanthium campanulate-globose; carpels 2-3 .............................................................................. L. holmgrenii

- Stems ascending; sheath lobes 8; hypanthium globose-urceolate; carpels 3-4......

L. adscendens

\section{Lachemilla cyanea D.F.Morales-B. \& Romol., sp. nov.}

urn:Isid:ipni.org:names:77199642-1

Figs $10-12$

Diagnosis. Lachemilla cyanea differs from L. ranunculoides (L.M. Perry) Rothm. and L. williamsii (L.M. Perry) Rothm by its hirsute pubescence, reniform basal leaves that have a blue-green color, and turbinate-campanulate hypanthium.

Type. PERU. Apurímac: Abancay Province, road Abancay - Cuzco, $23 \mathrm{~km}$ from Abancay, 13.59722S, 72.84083W, alt. 3423 m, 25 June 2012, Morales-Briones D.F. \& Uribe-Convers S. 246, (holotype: ID!, isotypes: HAO!, QCA!).

Description. Rosette herbs up to $10 \mathrm{~cm}$ long, branches decumbent, sparsely hirsute. Basal stipules $10 \mathrm{~mm}$ long, adnate to the petiole, sparsely hirsute, membranaceous, brown at base, free at apex. Basal leaves tri-parted, blade reniform in outline, $17-20 \times 25-26 \mathrm{~mm}, 3$ lobes, chartaceous, slightly plicate, lobes unequally obovaterhomboid, lateral lobes divided the length $1 / 2$ of the blade, margin dentate-incised, teeth $8-10$ on each of the lobes, lower and upper surface sparsely hirsute-villous; basal petiole $12-20 \mathrm{~mm}$ long. Distal stipules $7-8 \mathrm{~mm}$ long, connate and adnate to the petiole at base, free and incised at apex, leaf-like in texture. Distal leaves tri-parted, 8-10 $\times$ $8-12 \mathrm{~mm}$, lobes obovate-rhomboid, decreasing in size; distal petiole $1-2.5 \mathrm{~mm}$ long. Inflorescences axilar or terminal glomerulate cymes, flowers aggregate at the distal part. Floral bracts 1-2 $\mathrm{mm}$ long, free, incised, and ascending to slightly spreading; 2-6 flowers per inflorescence; pedicels $0.6-1 \mathrm{~mm}$ long, sericeous. Flowers $2-2.5 \mathrm{~mm}$ long; hypanthium turbinate-campanulate, green, glabrous outside and within; 4 episepals and sepals green to reddish at apex, straight, abaxially and adaxially glabrous; episepals triangular, $0.7-0.8 \times 0.3-0.4 \mathrm{~mm}$, apex acute; sepals triangular-ovate, $0.7-0.8 \times$ $0.5 \mathrm{~mm}$, apex acute; stamens 2 adnate to the floral disc; carpels 2, stigma clavate. Two achenes, ca. $1 \times 0.7-0.8 \mathrm{~mm}$, globose-ovoid.

Distribution and ecology. Lachemilla cyanea is only known from the Province of Abancay in the Department of Apurímac at ca. $3420 \mathrm{~m}$ in southern Peru (Fig. 6). This species occurs in the transition zone between the montane forest and the highelevation grassland dominated by dwarf shrubs and herbs. This species lives in sympatry with $L$. aphanoides and $L$. fulvescens. It was collected in flower and fruit in late June. 

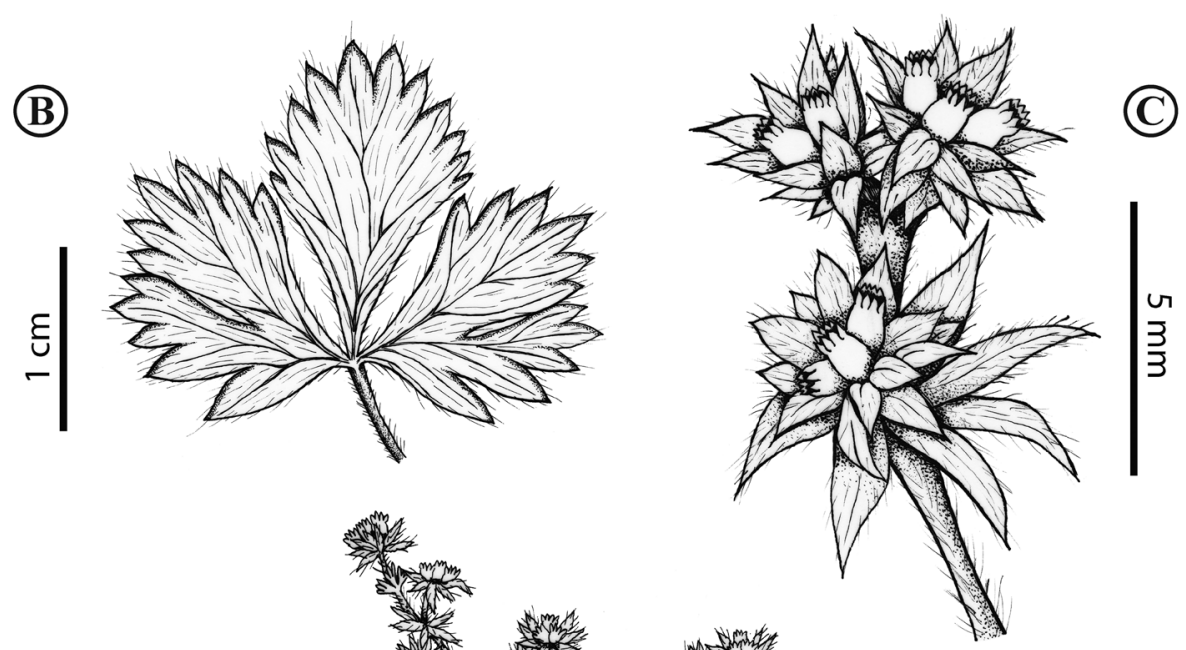

(D)

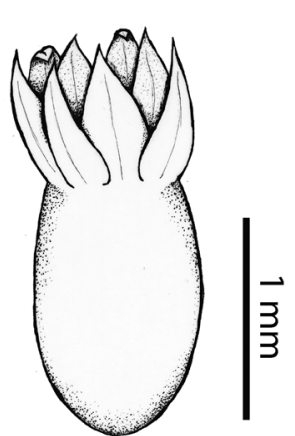

(A)
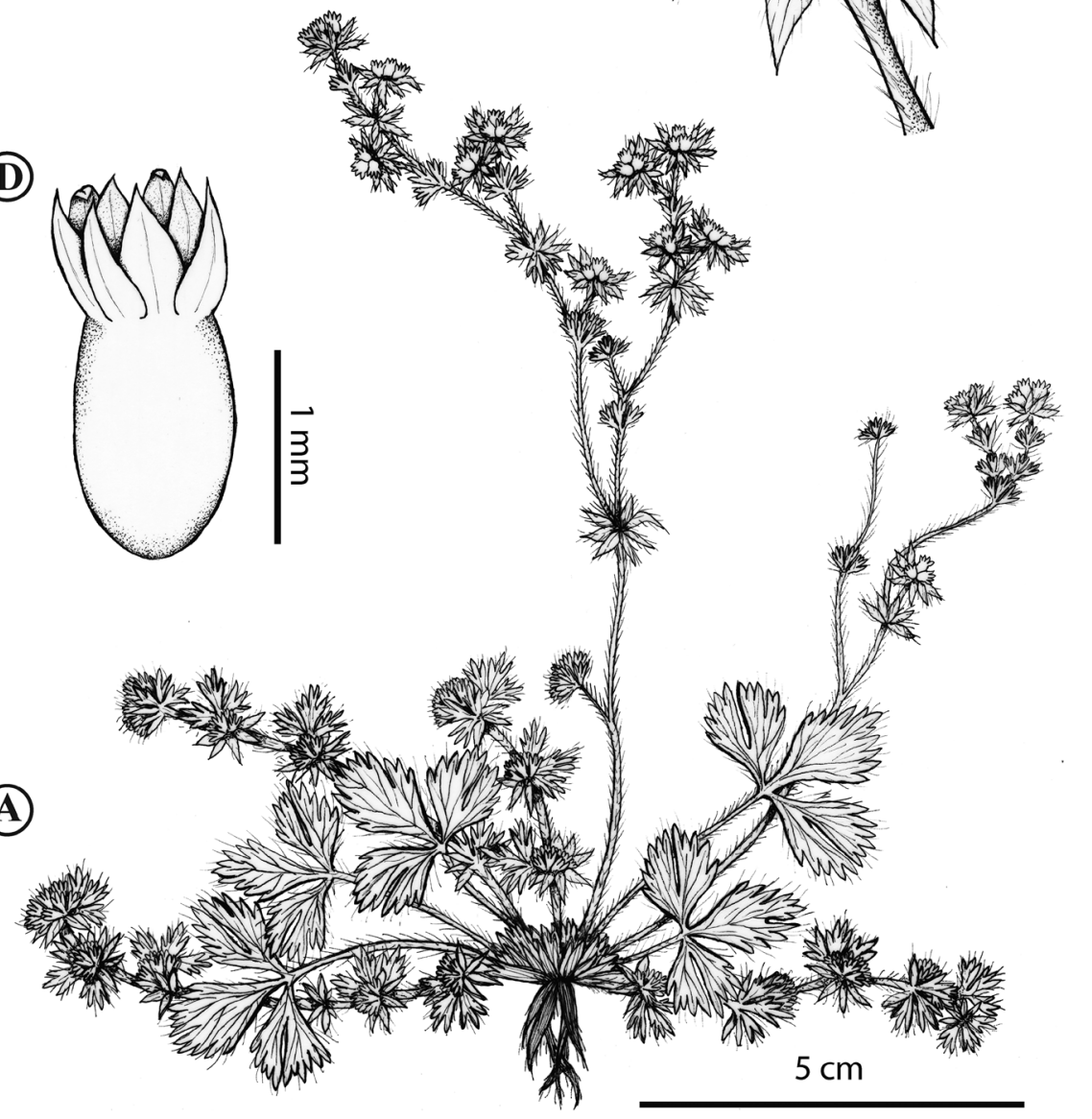

Figure 10. Lachemilla cyanea. A Habit B basal leaf $\mathbf{C}$ flowering branch $\mathbf{D}$ flower. Illustration by C. Rodríguez.

Etymology. The specific epithet refers to the blue-green color of the leaves.

Conservation status. Lachemilla cyanea is only known from the type locality in a zone severely impacted by human activities, including conversion to agriculture. Fol- 

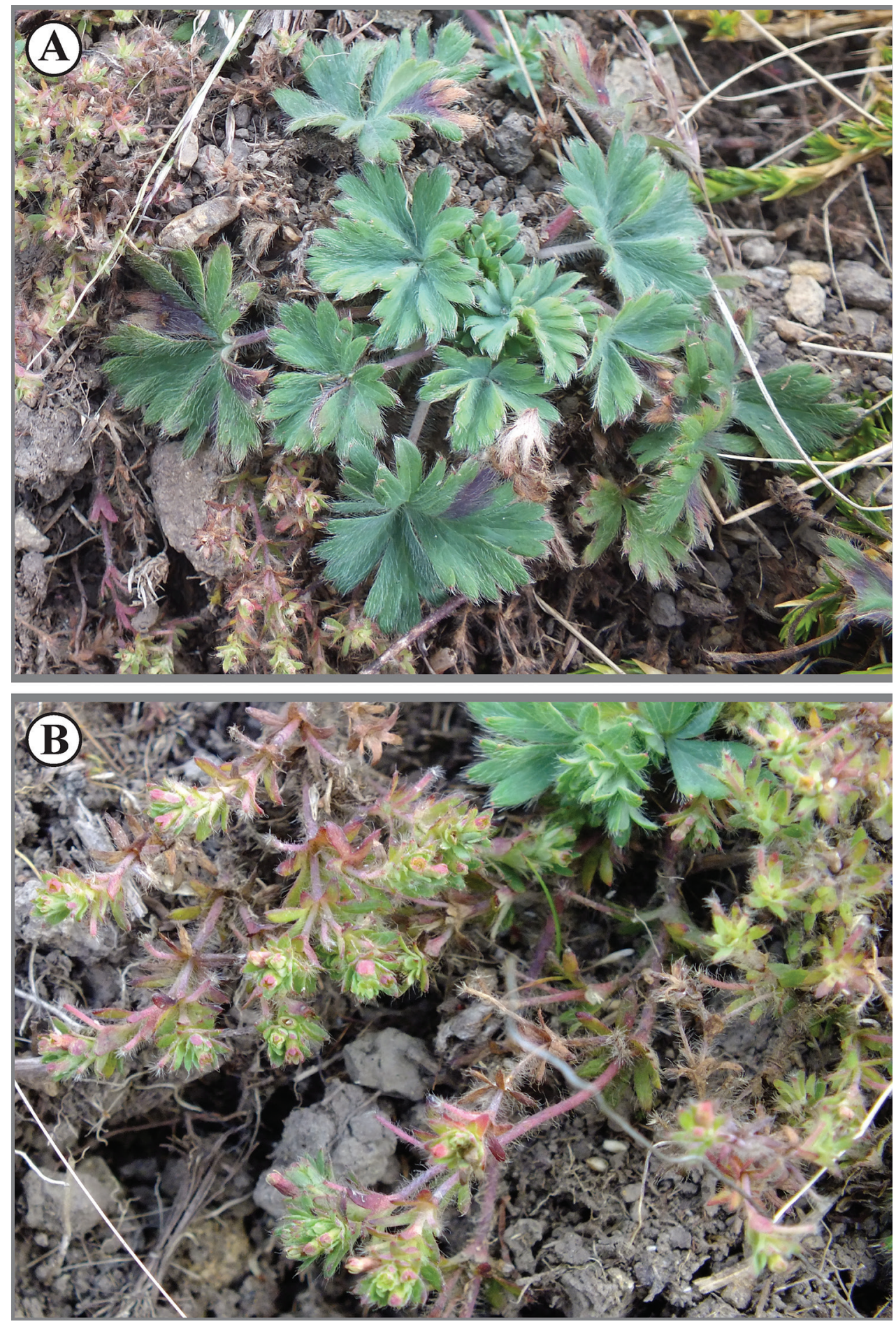

Figure I I. Lachemilla cyanea. A Habit B flowering branch. 


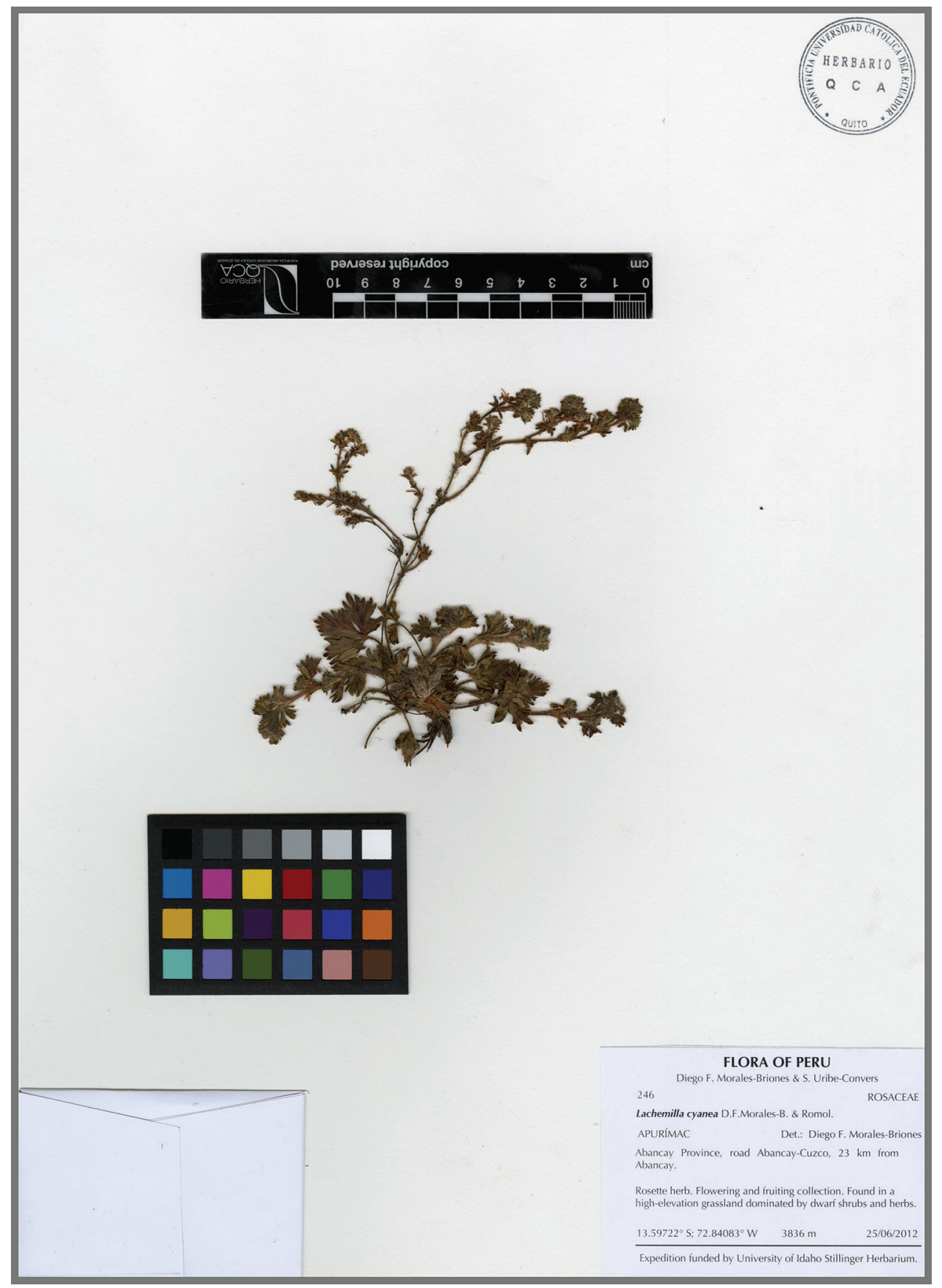

Figure I2. Lachemilla cyanea. Isotype collection: Morales-Briones D.F. \& Uribe-Convers S. 246 (QCA). 
lowing the IUCN (2017) guidelines, based on the reduced geographic distribution and altered land use at the type locality, this species should be categorized as endangered (EN), at least until other populations are discovered.

Notes. Lachemilla cyanea resembles L. ranunculoides in habit and glabrous flower, but differs in the reniform shape of the basal leaves in contrast to the orbicular-ovate shape of the latter. Moreover, L. cyanea has a turbinate-campanulate hypanthium while L. ranunculoides has an oblong-ventricose hypanthium. Lachemilla cyanea also resembles $L$. aphanoides in the tripartite basal leaves and glomerulate inflorescence, but differs in the rosette habit and decumbent branches, in contrast to the erect stems of $L$ aphanoides. Lachemilla cyanea is also similar to L. williamsii in habit, but the former has an overall hirsute pubescence and glabrous flowers with strictly two stamens, while the latter has a general villous pubescence, and villous flowers with up to four stamens (a characteristic only known in L. williamsii).

\section{Key to Lachemilla cyanea and similar species from the Central Andes}

Notes. Includes species with a general prostrate habit, tripartite basal leaves, and mainly glomerulate inflorescences (series Aphanoides, subseries 2; sensu Perry 1929). Accepted taxa and synonymy follows Morales-Briones et al. (2018a). Adapted from Perry (1929).

1 Herbs with creeping stems, mat-forming; lateral segments of the leaves entire; inflorescences loosely dichotomous; stipules entirely membranaceous.....L. rupestris

- Herbs with prostrate or loosely decumbent stems, villous or hirsute; lateral segments of the leaves variously lobed; inflorescences glomerulate cymes; stipules herbaceous at least at apex....................................................................2

2 Basal leaves lobes acute; flowers ca. $3 \mathrm{~mm}$ long, hirsute-villous to sericeous; stamens 2-4

- Basal leaves lobes obtuse; flowers ca. 2-2.5 mm long, glabrous or with scattering hairs on the hypanthium lobes; stamens 2 ........................................... 3

3 Plants densely sericeous-villous; sepals oblong-ovate............... L. grisebachiana

- Plants hirsute or glabrate; sepals ovate ...............................................4

4 Basal leaves subreniform; cauline leaves mainly subsessile; episepals reduced or absent; carpels 1-2

- Basal leaves orbicular or reniform; cauline leaves mainly petiolate; episepals conspicuous, carpels 2-4

5 Basal leaf blade reniform; hypanthium turbinate-campanulate; carpels 2

L. cyanea

- Basal leaf blade orbicular; hypanthium oblong-ventricose; carpels 2-4 


\section{Acknowledgements}

We are grateful to the curators of ANDES, CAS, COL, F, MEXU, HUT, HAO, ID, JE, MO, NY, QCA, TEX and USM for access or loans of their collections. We also thank Santiago Cordero and Carla Rodríguez for the illustrations, Daniela Cevallos for the Type images, and Simon Uribe-Convers for assistance during fieldwork. Funding for this work was provided by a Secretaría de Educación Superior, Ciencia, Tecnología e Innovación (SENESCYT) doctoral scholarship sponsored by the Instituto Nacional de Biodiversidad (INABIO) to D.F.M-B., Graduate Student Research Grants from the Botanical Society of America (BSA), the American Society of Plant Taxonomists (ASPT), the International Association of Plant Taxonomist (IAPT), and the University of Idaho Stillinger Herbarium Expedition Funds to DFM-B, and a National Science Foundation Doctoral Dissertation Improvement Grant to DCT for DFM-B (DEB1502049). KR was funded by the Pontificia Universidad Católica del Ecuador and the SENESCYT's 'Arca de Noé' Initiative-Project. Access to genomic and computational resources was granted through the University of Idaho Institute for Bioinformatics and Evolutionary Studies (IBEST) supported by an Institutional Development Award (IDeA) from the National Institute of General Medical Sciences of the National Institutes of Health (P30 GM103324).

\section{References}

Barrie FR (2015) Lachemilla (Focke) Rydb. In: Davidse G, Sousa Sánchez M, Knapp S, Chiang Cabrera F (Eds) Flora Mesoamericana: Saururaceae a Zygophyllaceae 2(3): 1-347.

Dillenberger MS, Wei N, Tennessen JA, Ashman TL, Liston A (2018) Plastid genomes reveal recurrent formation of allopolyploid Fragaria. American Journal of Botany 105(5): 862-874. https://doi.org/10.1002/ajb2.1085

Gaviria J (1997) Sinópsis del género Lachemilla (Focke) Rydberg (Rosaceae) para Venezuela. Plantula 1(3): 189-212.

IUCN (2017) Guidelines for using the IUCN Red List Categories and Criteria. Version 13. Prepared by the Standards and Petitions Subcommittee. http://www.iucnredlist.org/documents/RedListGuidelines.pdf [accessed: 14 Apr 2018]

Lemoine F, Entfellner JBD, Wilkinson E, Correia D, Felipe MD, Oliveira T, Gascuel O (2018) Renewing Felsenstein's phylogenetic bootstrap in the era of big data. Nature 556(7702): 452-456. https://doi.org/10.1038/s41586-018-0043-0

Miller M, Pfeiffer W, Schwartz T (2010) Creating the CIPRES science gateway for inference of large phylogenetic trees. Gateway Computing Environments Workshop (GCE): 1-8. https://doi.org/10.1109/GCE.2010.5676129

Morales-Briones DF (2016) Lachemilla mexiquense (Rosaceae), a new species from Mexico. PhytoKeys 62: 25-32. https://doi.org/10.3897/phytokeys.62.7953

Morales-Briones DF, Tank DC (2019a) Extensive allopolyploidy in the neotropical genus Lachemilla (Rosaceae) revealed by PCR-based target enrichment of the nuclear ribosomal 
DNA cistron and plastid phylogenomics. American Journal of Botany 106(2): 415-437. https://doi.org/10.1002/ajb2.1253

Morales-Briones DF, Tank DC (2019b) Data from: Extensive allopolyploidy in the neotropical genus Lachemilla (Rosaceae) revealed by PCR-based target enrichment of the nuclear ribosomal DNA cistron and plastid phylogenomics.

Morales-Briones DF, Romoleroux K, Kolár F, Tank DC (2018a) Phylogeny and Evolution of the Neotropical Radiation of Lachemilla (Rosaceae): Uncovering a History of Reticulate Evolution and Implications for Infrageneric Classification. Systematic Botany 43(1): 17-34. https://doi.org/10.1600/036364418X696897

Morales-Briones DF, Liston A, Tank DC (2018b) Phylogenomic analyses reveal a deep history of hybridization and polyploidy in the Neotropical genus Lachemilla (Rosaceae). The New Phytologist 218(4): 1668-1684. https://doi.org/10.1111/nph.15099

Perry LM (1929) A tentative revision of Alchemilla $\$$ Lachemilla. Contributions from the Gray Herbarium of Harvard University 84: 1-57. https://www.jstor.org/stable/41764062

Rambaut A, Suchard MA, Xie D, Drummond AJ (2014) Tracer v1.6. http://beast.bio.ed.ac. uk/Tracer

Romoleroux K (1996) 79. Rosaceae. In: Harling G, Andersson L (Eds) Flora of Ecuador 56: 1-152. University of Gothenburg/Riksmuseum/Pontificia Universidad Católica del Ecuador, Göteborg/Stockholm/Quito.

Romoleroux K (2004) The genus Lachemilla (Rosaceae) in the northern Andes of South America. Lyonia 7(1): 21-32.

Romoleroux K (2009) New species of Lachemilla (Rosaceae) from South America. Novon: A Journal for Botanical Nomenclature 19(4): 502-506. https://doi.org/10.3417/2006054

Romoleroux K, Morales-Briones DF (2012) Lachemilla jaramilloi and L. talamanquensis spp. nov. (Rosaceae) from Ecuador and Costa Rica. Nordic Journal of Botany 30(6): 732-736. https://doi.org/10.1111/j.1756-1051.2011.01413.x

Ronquist F, Teslenko M, van der Mark P, Ayres DL, Darling A, Höhna S, Larget B, Liu L, Suchard MA, Huelsenbeck JP (2012) MrBayes 3.2: Efficient Bayesian phylogenetic inference and model choice across a large model space. Systematic Biology 61(3): 539-542. https://doi.org/10.1093/sysbio/sys029

Rothmaler W (1935a) Alchemillae Columbianae. Trabajos del Museo Nacional de Ciencias Naturales - Serie Botanica 31: 1-52. http://bibdigital.rjb.csic.es/ing/Libro.php?Libro=710

Rothmaler W (1935b) Systematische Vorarbeiten zu einer Monographie der Gattung Alchemilla (L.) Scop. emend. II. Die systematische Gliederung der Gattung. Repertorium novarum specierum regni vegetabilis 38: 409-412. https://doi.org/10.1002/fedr.4870382603

Rothmaler W (1937) Systematische Vorarbeiten zu einer Monographie der Gattung Alchemilla (L.) Scop. VII. Aufteilung der Gattung und Nomenklatur. Repertorium novarum specierum regni vegetabilis 42: 164-173. https://doi.org/10.1002/fedr.19370421106

Stamatakis A (2014) RAxML version 8: A tool for phylogenetic analysis and post-analysis of large phylogenies. Bioinformatics (Oxford, England) 30(9): 1312-1313. https://doi. org/10.1093/bioinformatics/btu033 


\section{Appendix I}

Species and vouchers used in the phylogenetic analyses. Arranged by species name and authority, DNA number, and collector and number (herbarium code).

Outgroup: Alchemilla johnstonii Oliv.: 2015_358, B. Gehrke 364 (UZH). Alchemilla mollis (Buser) Rothm.: 2012_228_US, D.F. Morales-Briones 687 (ID). Aphanes cotopaxiensis Romol. \& Frost-Ols.: 2013_004_EC, D.F. Morales-Briones 276 (ID). Farinopsis salesoviana (Stephan) Chrtek \& Soják: 2016_580, B. Bartholomew 8364 (MO). Ingroup: Lachemilla adscendens (Rothm.) Rothm.: 2013_445_CO, D.F. Morales-Briones \& S. Uribe-Convers 429A (ID). Lachemilla andina (L.M. Perry) Rothm.: 2012_249_PE, D.F. Morales-Briones \& S. Uribe-Convers 218 (ID); 2012_379_EC, D.F. Morales-Briones et al. 122 (QCA). Lachemilla aphanoides (Mutis ex L. f.) Rothm.: 2012_246_PE, D.F. Morales-Briones \& S. Uribe-Convers 215 (ID); 2012_396_EC, D.F. Morales-Briones et al. 115 (QCA); 2013_446_CO, D.F. Morales-Briones \& S. Uribe-Convers 430 (ID); 2014_541_CO, D.F. Morales-Briones \& S. Uribe-Convers 550 (ID). Lachemilla argentea D.F. Morales-B. \& Romol.: 2013_447_CO, D.F. Morales-Briones et al. 431 (ID); 2013_475_CO, D.F. Morales-Briones et al. 459 (ID); 2014_507_CO, D.F. Morales-Briones \& S. Uribe-Convers 514 (ID); 2014_516_CO, D.F. Morales-Briones \& S. Uribe-Convers 523 (ID). Lachemilla barbata (C. Presl) Rothm.: 2012_260_PE, D.F. Morales-Briones \& S. Uribe-Convers 229 (ID). Lachemilla bipinnatifida (L.M. Perry) Rothm.: 2013_428_BO, D.F. Morales-Briones et al. 326 (ID). Lachemilla cyanea D.F. Morales-B. \& Romol.: 2012_277_PE, D.F. Morales-Briones \& $S$. Uribe-Convers 246 (ID). Lachemilla diplophylla (Diels) Rothm.: 2012_229_PE, D.F. Morales-Briones \& S. Uribe-Convers 198 (ID). Lachemilla equisetiformis (Trevir.) Rothm.: 2012_108_VE, A.J.P. Martin 740 (QCA). Lachemilla erodiifolia (Wedd.) Rothm.: 2012_244_PE, D.F. Morales-Briones \& S. Uribe-Convers 213 (ID). Lachemilla frigida (Wedd.) Rothm.: 2012_300_PE, D.F. MoralesBriones \& S. Uribe-Convers 269 (ID). Lachemilla fulvescens (L.M. Perry) Rothm.: 2014_551_CO, D.F. Morales-Briones \& S. Uribe-Convers 560 (ID). Lachemilla galioides (Benth.) Rothm.: 2012_348_EC, K. Romoleroux et al. 4403 (QCA). Lachemilla hirta (L.M. Perry) Rothm.: 2012_317_EC, K. Romoleroux et al. 4588 (QCA); 2012_343_EC, K. Romoleroux et al. 4389 (QCA). Lachemilla hispidula (L.M. Perry) Rothm.: 2012_310_EC, K. Romoleroux et al. 4470 (QCA). Lachemilla holmgrenii Rothm.: 2012_347_EC, K. Romoleroux et al. 4397 (QCA). Lachemilla holosericea (L.M. Perry) Rothm.: 2012_395_EC, D.F. Morales-Briones \& K. Romoleroux 161 (QCA); 2014_479_CO, D.F. Morales-Briones et al. 485 (ID). Lachemilla jamesonii (L.M. Perry) Rothm.: 2012_350_EC, K. Romoleroux et al. 4387 (QCA). Lachemilla jaramilloi Romol. \& D.F. Morales-B.: 2012_006_EC, D.F. Morales-Briones \& S. Uribe-Convers 193 (ID); 2012_371_EC, D.F. Morales-Briones et al. 115 (QCA). Lachemilla lechleriana (Griseb.) Rothm.: 2012_271_PE, D.F. Morales-Briones \& S. Uribe-Convers 240 (ID). Lachemilla llanganatensis Romol.: 2012_363_EC, D.F. Morales-Briones et al. 105 (QCA). Lachemilla mandoniana (Wedd.) Rothm.: 
2012_370_EC, D.F. Morales-Briones et al. 114 (QCA). Lachemilla mexiquense D.F. Morales-B.: 2015_233_MX, D.F. Morales-Briones \& P. Tenorio-Lezama 683 (ID). Lachemilla moritziana Dammer: 2013_443_CO, D.F. Morales-Briones \& S. Uribe-Convers 427 (ID). Lachemilla nivalis (Kunth) Rothm.: 2012_349_EC, D.F. Morales-Briones \& M.F. Latorre-Barragán 11 (QCA). Lachemilla orbiculata (Ruiz \& Pav.) Rydb.: 2012_377_EC, D.F. Morales-Briones et al. 121 (QCA). Lachemilla pectinata (Kunth) Rothm.: 2012_326_EC, K. Romoleroux et al. 4706 (QCA). Lachemilla perryana (Rothm.) Rothm.: 2012_380_EC, D.F. Morales-Briones et al. 123 (QCA). Lachemilla pinnata (Ruiz \& Pav.) Rothm.: 2012_251_PE, D.F. Morales-Briones \& S. UribeConvers 220 (ID). Lachemilla polylepis (Wedd.) Rothm.: 2012_359_CO, P. Sklenár FAA652 (PRC). Lachemilla pringlei Rydb.: 2015_150_MX, D.F. Morales-Briones \& P. Tenorio-Lezama 595 (ID). Lachemilla procumbens (Rose) Rydb.: 2015_200_ MX, D.F. Morales-Briones \& P. Tenorio-Lezama 648 (ID). Lachemilla pseudovenusta (Rothm.) Rothm.: 2012_275_PE, D.F. Morales-Briones \& S. Uribe-Convers 244 (ID). Lachemilla purdiei (L.M. Perry) Rothm.: 2014_501_CO, D.F. Morales-Briones \& S. Uribe-Convers 508 (ID). Lachemilla ranunculoides (L.M. Perry) Rothm.: 2012_240_ PE, D.F. Morales-Briones \& S. Uribe-Convers 209 (ID). Lachemilla repens (C. Presl) Rothm.: 2012_263_PE, D.F. Morales-Briones \& S. Uribe-Convers 232 (ID). Lachemilla rothmaleriana D.F. Morales-B. \& Romol.: 2014_486_CO, D.F. Morales-Briones \& S. Uribe-Convers 492 (ID); 2014_499_CO, D.F. Morales-Briones \& S. Uribe-Convers 506 (ID). Lachemilla rupestris (Kunth) Rothm.: 2012_394_EC, D.F. Morales-Briones et al. 157 (QCA). Lachemilla sarmentosa (L.M. Perry) Rothm.: 2013_396_BO, D.F. Morales-Briones et al. 292 (ID); 2013_413_BO, D.F. Morales-Briones et al. 309 (ID). Lachemilla sibbaldiifolia (Kunth) Rydb.: 2015_154_MX, D.F. Morales-Briones \& P. Tenorio-Lezama 599 (ID). Lachemilla sprucei (L.M. Perry) Rothm.: 2012_340_ EC, K. Romoleroux et al. 4474 (QCA). Lachemilla standleyi (L.M. Perry) Rothm.: 2016_614_CR, K. Romoleroux et al. 5023 (QCA). Lachemilla steinbachii Rothm.: 2013_415_BO, D.F. Morales-Briones et al. 311 (ID). Lachemilla talamanquensis Romol. \& D.F. Morales-B.: 2012_334_CR, K. Romoleroux et al. 5008 (QCA). Lachemilla tanacetifolia Rothm.: 2012_331_EC, K. Romoleroux et al. 4396 (QCA). Lachemilla uniflora Maguire: 2012_362_EC, D.F. Morales-Briones et al. 75 (QCA); 2012_385_EC, D.F. Morales-Briones et al. 130 (QCA). Lachemilla velutina (S. Watson) Rydb.: 2015_162_MX, D.F. Morales-Briones \& P. Tenorio-Lezama 607 (ID). Lachemilla venusta (Schltdl. \& Cham.) Rydb.: 2015_157_MX, D.F. Morales-Briones \& P. Tenorio-Lezama 602 (ID). Lachemilla verticillata (Fielding \& Gardner) Rothm.: 2012_339_CR, K. Romoleroux et al. 5007 (QCA). Lachemilla vulcanica (Schltdl. \& Cham.) Rydb.: 2012_250_PE, D.F. Morales-Briones \& S. Uribe-Convers 219 (ID); 2015_171_MX, D.F. Morales-Briones \& P. Tenorio-Lezama 617 (ID). Lachemilla williamsii (L.M. Perry) Rothm.: 2013_402_BO, D.F. Morales-Briones et al. 298 (ID). 